\title{
Perception of public managers on the sustainability of sports mega-events: the case of the 2014 World Cup in Brazil
}

\author{
Percepção dos gestores públicos sobre a sustentabilidade de megaeventos \\ esportivos: o caso da Copa do Mundo de 2014 no Brasil
Percepción de los gestores públicos sobre la sostenibilidad de megaeventos deportivos: el caso de la Copa del Mundo de 2014 en Brasil

\author{
César Ricardo Maia de Vasconcelos ${ }^{1}$ \\ Fernando Cabral de Macedo Filho ${ }^{1}$
}

Recebido em 31/07/2018; revisado e aprovado em 06/05/2019; aceito em 22/05/2019

DOI: http://dx.doi.org/10.20435/inter.v21i2.2103

\begin{abstract}
The realization of the 2014 World Cup in Brazil generated meaningful transformations in the host cities. These transformations brought concerns over the sustainability of a mega-sport event. The present study tried to understand the sustainability resulting from the World Cup in the city of Natal, Brazil, from the perspective of local public managers. This qualitative, descriptive research, whose data were inductively analyzed, used a semi-open interview composed of 24 semi-structured questions in order to obtain information from the public managers at local and state levels and who are linked to the event. As a result, the managers involved concluded that the 2014 World Cup in Natal did not serve sustainability neither leave any sustainable effects. It was also observed that the lack of sustainability was due to the lack of adequate planning and technical projects, as well as to the lack of organization and social participation in the preparation and followup of the works and actions necessary for its accomplishment. Among the propositions of new works, there is the recommendation to analyze how the public managers and the normative regulations are dealing with sustainability in the planning and in the projects for the realization of two other mega-sport events, the FIFA 2018 World Cup in Russia and the FIFA 2022 World Cup in Qatar.
\end{abstract}

Keywords: public managers; sustainability; social participation.

Resumo: A realização da Copa do Mundo de 2014 no Brasil gerou transformações significativas nas cidades que a sediaram. Essas modificações fizeram surgir preocupações sobre a sustentabilidade de um megaevento esportivo. O presente estudo se destinou a compreender a sustentabilidade decorrente da realização da Copa do Mundo em Natal, Rio Grande do Norte, RN, a partir da visão de gestores públicos potiguares. Qualitativa, esta pesquisa descritiva, cujos dados foram analisados indutivamente, utilizou-se de entrevista semiaberta composta de 24 questões semiestruturadas para obter informações dos gestores públicos das esferas municipal e estadual vinculados ao evento. Como resultado, percebeu-se por parte dos gestores envolvidos que a Copa do Mundo de 2014 em Natal, RN, não atendeu à sustentabilidade e tampouco deixou efeitos de sustentabilidade. Observou-se, também, que a ausência de sustentabilidade se deu em razão da inexistência de planejamentos e projetos técnicos adequados, bem como pela falta de organização e participação da sociedade no planejamento e acompanhamento das obras e ações necessárias à sua realização. Entre as proposições de novos trabalhos, recomendou-se analisar como os gestores públicos e as disposições normativas estão tratando a sustentabilidade no planejamento e nos projetos para a realização de outros megaeventos esportivos, a Copa do Mundo da FIFA de 2018 na França e a Copa do Mundo de 2022 no Qatar.

Palavras-chave: gestores públicos; sustentabilidade; participação social.

Resumen: La realización de la Copa del Mundo de 2014 en Brasil generó transformaciones significativas en las ciudades que la albergaron. Estas modificaciones hicieron surgir preocupaciones sobre la sostenibilidad de un megaevento deportivo. El presente estudio se destinó a comprender la sostenibilidad resultante de la realización de la Copa del Mundo en Natal, Rio Grande do Norte, RN, a partir de la visión de gestores públicos locales. En este sentido, esta investigación descriptiva, cuyos datos fueron analizados indutivamente, se utilizó de entrevista semiabierta compuesta de 24 preguntas semiestructuradas para obtener informaciones de los gestores públicos de las esferas municipal y estatal vinculados al evento. Como resultado, se percibió por parte de los gestores involucrados que la Copa del Mundo de 2014 en Natal, RN, no atendió a la sostenibilidad y tampoco dejó efectos de sostenibilidad. Se observó también que la ausencia de sostenibilidad se dio en razón de la inexistencia de planificaciones y proyectos técnicos adecuados, así como por la falta de organización

${ }^{1}$ Universidade Potiguar (UnP), Natal, Rio Grande do Norte, Brasil. 
y participación de la sociedad en la planificación y seguimiento de las obras y acciones necesarias para su realización. Entre las propuestas de nuevos trabajos se recomendó analizar cómo los gestores públicos y las disposiciones normativas están tratando la sostenibilidad en la planificación y en los proyectos para la realización de otros megaeventos deportivos, la Copa Mundial de la FIFA de 2018 en Francia y la Copa del Mundo de 2022 en Qatar.

Palabras clave: gestores públicos; sostenibilidad; participación social.

\section{INTRODUCTION}

The 20th World Cup games, which took place in Brazil in 2014, may be considered one of the planet's largest sport events and, as such, generated impact in several areas throughout the country. From these, we can highlight major urban interventions that took place in the host cities, the new stadiums (both built and remodeled) and the major urban mobility works, which must play an accelerator role in restructuring city space. Notwithstanding, we noticed this expansion happened from the infrastructure redistribution and urban equipment throughout the city.

The territory transformation in Brazilian cities that hosted the 2014 World Cup enabled the debate over a way of planning which would be for the realization of a single event that would force the cities to meet the demands from the Fédération Internationale de Football Association (FIFA), its sponsors and perspective tourists. Thus, according to Gonçalves (2013), the citizens' needs were put aside since rarely, or almost never, the FIFA-imposed needs meet the demands of the people who live in the host cities, and, according to Vico, Uvinha and Nuno (2018), they can make people dislike the event due to a mistaken perception of its objective.

However, to DaCosta (2008) and Mofokeng and Ndlovu (2018), the World Cup of Soccer is seen as one of the biggest events organized on a global scale and which creates relevant expectations in media, business, tourism and the country's image. Furthermore, due to the urban regeneration, improvement in the means of transportation, increase in civil construction, among many other actions which somehow influence local development, highlighting that the impacts considered safe can shift from positive to negative. Based on this, and in order to guarantee the relationship between capital and urban space, FIFA launches its set of demands and strategies, besides maximizing its profits and minimizing its costs, making sure the projects that will be left as legacy meet not only the spectacle needs but contribute to these legacies' sustainability as well .

The Brazilian Department of Sports, however, and according to Cottle, Canto Capella and Meirinho (2013), anticipated a Brazilian economical general impact in 2014 which was over 100 billion dollars, opening thousands of permanent and temporary jobs. The fact that up to May 2012, only 59\% of the World Cup construction work had started, led the Federal Government to change their procedures in order to approve projects, and created the "exceptionality decree", which served to speed up approvals for the World Cup infrastructure projects.

An event like the World Cup was described as "mega" due to its grandeur in terms of audience and because of the impacts on the hosts' economy and finances, media and TV, sports facilities and social-cultural and political traces. Also, in order to reach expressive results, the planning developed by the event organizer entity Local Organizing Committee (LOC) - was primordial for the criteria established for before, during and after the competition. However, we didn't find any analyses in the local media associated to the public managers' assertiveness about the topic and none about sustainable development, which, by the size of the event, should demand studies or even instruments that could join economic development to environmental and social responsibilities. 
Notwithstanding, in relation to social-economic responsibility which tries to bring us a better future, researches as the ones done by Mendes (2009), Ernst and Young Brasil (2010), Bacha, Santos and Schaun (2010), Monzoni Neto, Pinto Oliveira and Koszka Kiss (2011) and Andrade (2013), and showed that economic sustainability, besides being the foundation of a stabilized and fairer society, enables sustainable development. However, in none of these researches were we able to see any concern to analyze the sustainability applied to events like the World Cup.

When it comes to academic investigation on mega-events, these have been fairly explored by the researchers. Tavares (2011) highlights that the fact Brazil has hosted major events of distinct natures, all from the international spectrum (e.g., Pan American Games, World Military Games, World Worker's Games, World Cup and Olympic Games), it forced the academic world to "dedicate time and resources in analyses efforts, comprehension, critics and perspective of the so-called mega-sport events" (p. 12). But we should point out that, as stated by DaCosta (2008), the choice for Brazil to host the 2014 World Cup widened the importance of production of knowledge about sports relations and recreation and tourism time with the environment.

This way, facing the little technical material or the shortage in scientific research about mega-sport events and sustainability, this article aims at bringing some light upon the relationship between the sustainability forecast in the norms which were instituted to guarantee the World Cup realization and the state public managers' perception linked to planning actions and execution about the event sustainability. From the preliminary studies done, we reached the following conflict: what is the public state managers' perception about the 2014 World Cup sustainability in Natal, RN?

Besides this introductory section, this article is structured as a theoretical reference which addresses the following topics: mega-sport events, world cup: an issue of State, sustainability and public management. The third section presents the methodological procedures and emphasizes the qualitative research as a method adopted in order to reach the objective proposed. The fourth section focuses on the results' display and discussion. Then, the final considerations are presented in section five.

\section{THEORETICAL REFERENCE}

\subsection{Mega-sport events}

According to Tavares (2011), The World Cup, the Olympic Games, international fairs and expositions have the fundamental models which can also be found in mega-events. However, according to the author, due to the advancement in communication technology, which enables the international sporting event broadcasting, as well as the promotional opportunities they bring to the host cities, both the World Cup and the Olympics ended up taking a mega-event characteristic for most people, whereas fairs and expositions come second.

Still, according to Tavares (2011), as the term mega-events gained visibility in the social scenery, it also gained several meanings as time went by. In the common sense, it is related to major sport competition, nation-wide most of the times. From the media point of view, especially from the professionals connected to sports, it is usually about international events which gather several athletes within a very short period of time, usually limited to one month, and with great impact, both social and economic. 
Capel (2010, p. 1) defends the thesis that the World Cup is about a great development opportunity to the host countries. Insomuch that, according to the author:

The cities struggle to promote their image to the world and for the consequences it has over tourism and economic activity. The inversion allows the improvement of infrastructure, increases the international visibility, improves some sectors in the city, and adds up to the hotel sector and the qualification of tourist agents. Also, a major sport event activates consumption and allows for fighting off the processes of industrial dismantling.

In this same sense, Pereira (2012, p. 1) adds:

The realization of the World Cup in our country can change the life of many Brazilians. From a macro perspective, it is easy to understand that the competitions which are approaching will bring the inevitable visibility of our economic market, the possibility to promote the economy, and the opening of international channels for business, besides the use of sport as a way to insert young people from different social layers, and prevention against the devilish and malignant drug effects, since, besides bringing health benefits, sports also bring moments of pleasure and social interaction.

However, there are some authors who do not have such an optimist perspective as to the impacts or consequences related to mega-events like the World Cup, since they believe it serves more its organizers' interests than actually society itself. On possible profit which may come from this event, Estender, Volpi and Fittipaldi (2011, p. 1) question: "Will the World Cup be able to push the host nation's economy that justifies the high risks and costs?". And they go on:

An analyses of the 1994 World Cup done in the United States suggests that the economic impact can't justify this magnitude of costs and that the cities experience accumulated losses from US\$ 5,5 to US\$ 9,3 billion, against an estimated gain of US\$ 4 billion. Perspective host countries must consider carefully whether hosting the World Cup is an honor or a burden.

In order to endorse this positioning, however, focused on the impacts events like this can bring over public finances and on services needed to the population welfare, Figueiredo, Lima and Pontes de Araújo (2013, p. 5) adds that an investment of this nature can become "worrying as to the choice of the host cities, especially because it can cause problems in public finances due to the high resource available and to the long-term debt". The authors alert that the construction of arenas and other expenses to the realization of a mega-sport event is financed by the host city or country, and the money probably comes from public maneuvers.

Besides the cost of these constructions, the lack of planning can also bring situations of underutilization of the infrastructures built, which, after the realization of the mega-event, can become useless for their previous purposes. Equally worrying is what comes from the considerations by Preuss (2007), Vico, Uvinha and Nuno (2018) and Amponsah, Ahmed, Kumar and Adams (2018), since it's the social impacts generated by mega-events that very frequently dislodge residential areas previously occupied by low income people in order to have new sporting facilities built, which disturbs these residents lifestyles. The justification is said to be the necessity of modernizing urban space, even if it seems to deal only with a way to expel those who are socially marginalized. Furthermore, the authors underline, even those who remain in their places are forced to move from the neighborhood where they lived due to the impoverishment of these areas which, because of the intense valuing generated by tourists' inflow, by infrastructure works and by the country's awareness, among other improvements, become inaccessible for their purchasing power. 
With this scenery, a mega-event, in the opinion of DaCosta (2008) and Mofokeng and Ndlovu (2018), can be defined by the number of participants or by the process - which can be short-lasting but have an intense preparation and, intermittently, is always operating within the range of millions of participants. However, to Estender, Volpi and Fittipaldi (2011), the term mega-events is associated to short-lasting events with long-term consequences for the host cities. These consequences, as added by some authors, may refer to aspects as infrastructure provision, economic and social impacts, city image renewal or creation through media and especially the TV.

\subsection{World Cup: a STATE matter}

According to Gastaldo (2009), soccer has become an activity of huge social importance with consequences which transcend the field and becomes a State matter. On this, Domingues, Betarelli Júnior and Magalhães (2011) states that almost all the investment is supported by public organs financing, whose financial return is estimated not only over taxes and opportunities of new businesses but also on improvements in several sectors.

However, according to Gastaldo (2009), we can't consider the huge influence the press plays on the social field, since, in the quality of articulator of meanings which will be lent to the facts while others are eliminated, it builds a definition of reality that will be taken as true by most of the public. Even though it doesn't determine nor condition behaviors or actions, as reminded by the author, it collaborates effectively with the maintenance of a certain order within society. Luckily, even if it doesn't add up to a certain culture a high value to soccer or even if this value already exists, however, without the desired intensity to foment consumption in a way to enable the exploit directed to profit, the necessity for the event ends up being developed from the strategies which transform the sport into an article or merchantable product.

On a study ordered by the Organizing Committee of the Brazilian candidateship to measure the economic impact of the 2016 Olympics on the Brazilian economy, Domingues, Betarelli Júnior and Magalhães (2011) estimated that, up to 2016, something around 22 billion dollars will be invested in Brazil due to the Olympic and Paralympic games. From 2017 to 2027, the estimates are even higher, with values reaching 27 billion dollars (according to data supplied by the Presidency Social Communication Secretary).

\subsection{Sustainability}

According to Silva and Grassi Mendes (2005), the sustainability problem has played a fundamental role as a reflection possibility about more adequate development practices to a contemporary society in persistent transformation. Aware of the harmful impacts to the environment after centuries of intense industrialization, the organizers of high-proportioned events try to adequate to the scenery of ecological crisis that has been so discussed in this new century.

Furthermore, with the intention of facing the scenery brought by Silva and Grassi Mendes (2005), and according to Jacobi (2003), we have two central lines of thought which have fed the discussions: the first one defends the population and industry growth freezing as a way to reach balance between economy and environment, and the second one, on the other hand, turns to criticizing the actual lifestyle and believes it is possible to harmonize the present and future human needs through sustainability, both social, economic and ecologic. According to the author, this 
second line of thought aims at maximizing ecosystems' production according to human interests and, thus, it stands out since it highlights the necessity to invert auto-destructive processes of development based on abuse against nature.

Jacob (2003) emphasizes that in this last line of thought the concern about considering dimensions which cover economic, social and biophysical matrix as sustainability criteria due to a notion which considers not only the need to reduce the use of resources or population control leaves no doubt. This trend or, in other words, this view of sustainability has grown stronger and stronger, especially through the view which started on Agenda 21, which proposes, as a plan of action for the development, an approach that has plurality, diversity, multiplicity and heterogeneity as guides. All this because, as one thinks about a model of sustainable development, one must be aware it is about a project applied on and for society and, thus, subject to economic and social aspects.

Mikhailova (2004), on the other hand, defines sustainability as the capacity to maintain an activity continuously, in a way that the exploration of a given natural resource, done in a sustainable way, may happen forever. In order for this to be possible, the use of resources can't lead to the exhaustion of current reserves, so that the future generations may use them as stocks which can be applied as material capital.

Among the proposals commented on sustainability, Sachs (1993) adopts what he determines as sustainable development movement, which is based on the perception of respect to Earth's natural resources. As these resources can be eliminated through global catastrophes, both social and environmental, we must emphasize that every nation and government, or every member of the organized, civil society, must be willing to act collectively to find more sustainable development solutions.

\subsection{Sustainability and public management}

The conception of a sustainable event involves the discussion of four main topics about sustainability, which are economy, society, environment and politics, as defended by Jacobi (2003). All this because, as the risks of an event must be administered as not to bring any environmental drawbacks, the existence of economic improvement in every society sector they reach becomes relevant, as well as the possibility of people wisely using the natural resources favored by sustainability policy, which may lead them to think about the importance of protecting the environment for future generations.

Considering the necessity of articulation between these four pillars of sustainability, the Brazilian government launched the Environment and Sustainability Agenda, present in BRASIL (2014), whose mission was to "suggest public policies and necessary, efficient and transparent technical solutions which may guarantee the development of a legacy connected to the country's strategic interests from the realization of the 2014 FIFA World Cup". This way, through the Environment and Sustainability Theme Chamber, the Federal Government presented, as some of their objectives, the promotion of structuring actions which would guarantee both sustainability and protection to the environment, as well as the articulation of sustainability initiatives and the use of water in a rational way.

According to Monzoni Neto, Pinto Oliveira and Koszka Kiss 2011), during the 2006 World Cup, done in Germany, they tried to aggregate sustainability trying not to affect the economic 
participation in the event. Being the first in the world to use the Green Goal, a FIFA program to reduce $\mathrm{CO}_{2}$, that is, a plan which consists in enabling environmental sustainability, the Germany World Cup planned ambitious goals distributed in areas related to climatic changes, mobility, energy and waste disposal. And it goes on. The 2006 World Cup Organizing Committee, along with the Öko Institute (head-quartered in Germany) decided to plan a zero-emission event, as a way to demonstrate how much the event could be voluntarily equalized. At the end of the event, a total of 92,000 tons of $\mathrm{CO}_{2}$, which corresponded to a decrease of $19 \%$ compared to the 100,000 tons estimated for the event. According to the organizers, this successful result happened thanks to a combination of intensive use of public transportation and the implementation of urban mobility projects during the months before the World Cup. According to the authors, the same model was tried to be implemented four years later, in the South Africa World Cup, but they didn't reach the expected results. Even though one of the Green Goal's objectives for this World Cup was that of reaching the same levels of Carbon from the previous Cup, the emission quantity for the event was estimated at around 896,000 tons. In comparison, according to Monzoni Neto, Pinto Oliveira and Koszka Kiss (2011, p. 7), this was "eight times more the emission estimated for the Germany World Cup, not including the international transport emissions, which would add up to $1,856,000$ tons of Carbon dioxide". In relation to the 2014 Brazil World Cup, considering the reality complexity of the experience in previous Cups, new questions arouse, which needed a more incisive approach than simply concept information or principle orientation on environment protection. However, at least when it comes to Carbon reduction goals, Brazil promised to adopt the neutralization as a very clear guideline, also in terms of legislation proposal through the Law Project 7421/2010, going on in the Lower House, and which tries to establish the GHG emission neutralization obligatoriness that came from the Brazil World Cup of Soccer.

\section{METHODOLOGY}

\subsection{General considerations}

From the problem approach point of view, the present study is seen as a qualitative one, carried out under a non-constructivist paradigm and turned to deepening the comprehension, not to expanding it (BODDY, 2016), on which the personal experience and intuition worked together to help to perfect theories and experiments (STAKE, 2010 p. 21), that is, "it means the reasoning is based primarily on perception and human comprehension", which can't be translated into numbers but expressed in words as highlighted by Miles and Huberman (2003), or presented as important to understand the process variables and not just the outcome variables, as stressed by Achterberg and Arendt (2008), Yin (2016) and Boddy (2016). And, even if for some objectors the qualitative study presents weaknesses, like subjectivity, slow and tendentious contributions, for other professionals, subjectivity "is not seen as a weakness, or something that must be eliminated, but as an essential element to understand human activity", says Stake (2010 p. 39).

The qualitative researchers respectfully worry about the observation validation, and the phenomena studied by them, as said by Stake (2010), are usually long, casual and involving. It usually takes a long time to understand how everything works, that is, it requires a lot of work and it is expensive. To scholars like Stake (2010, p. 29), "this is more a labor of love than of science". In short, the natural environment is the direct source for data collection and the 
researcher is the key tool. Under this view, Mintzberg (1979, p. 584), digested: "data do not produce theory - only researchers do". This is a descriptive study and the data are analyzed inductively.

As to goals, this research can be classified as exploratory, once, according to Creswell (2014, p. 29), "one of the main reasons to lead a qualitative study is that it is exploratory", that is, it can be used to search for more information about a certain topic of which little is known or about which a lot is known, in order to gain new knowledge, as underlined by Stern (1980) and Glaser and Strauss (2017). Actually, as stated by Charreire Petit and Durieux (1999), the exploratory research is the process through which the researcher aims at offering innovative theoretical results.

Despite the technical procedures, the research can be seen as bibliographical and documental. The first one for having been set from theoretical references published in documents, that is, made up especially by books, specialized periodicals and with material from the internet. Among the advantages, as explained by Diehl and Tatim (2004, p. 58), "is the fact that these documents are a rich and stable data source". The latter one for having been implemented from material which did not have any analytical treatment or, according to Diehl and Tatim (2004, p. 59) "still can be re-elaborated according to the work objective". Even as guided by Severino (2016), it can be used as a document research source as long as it is wide, that is, it is not only about print document analyses, but also about photos, movies, recordings and legal documents, as is the case of those notably connected to the realization of the Brazil World Cup. Besides, as taught by Silva et al. (2009), as an investigation method of social reality, this type of research can be used both in the positive approach as well as in those of comprehensive character, more critically focused, since the objective is that of understanding the sustainable development elements promoted by the world soccer championship.

On the data collection technique, we adopted a semi-open interview composed of semistructured questions as a tool employed in order to get information from the public state and local managers involved in the 2014 World Cup in Natal. We should mention that the adoption of such a technical procedure happened due to the fitting of the objective desired in the research, for, as guided by Thums (2003), Andrade Martins and Theóphilo (2016) the basic purpose of an interview is to obtain information in a direct way together with the interviewee through a dialogue. As reinforcement to the adoption of this technique, we should highlight that, to Minayo (2012) and Yin (2016), through the interview we get information given in the individual speech, which can be translated into a system of values, norms and symbols, transmitted by the speaker as a representation signal in certain groups.

Under another perspective, Severino (2016, p. 123) observed that "the data collection is done on the natural conditions under which the phenomena take place, so they are directly associated without the intervention and handling from the researcher". And Thums (2003) and Andrade Martins and Theóphilo (2016), on the other hand, states that there is a disadvantage in the realization of data collection through an open interview, such as the interview duration, since there are people who change the subject a lot and this can muddle the dialogue discourse, the additional reason why a semi-open interview, with semi-structured questions, was the procedure we adopted for data collection. Furthermore, in the semi-structured format, the informer can discuss about experiences from a central topic led by the researcher, besides being able to give free and spontaneous answers. 


\subsection{Data collection}

The 9 (nine) public state managers were divided into two groups according to the public administration cluster to which they are connected: local (Public Works Department Secretary, Urban Mobility Department Deputy Secretary, Environment and Urbanism Department Secretary, Sport and Leisure Department Secretary and Tourism Department Secretary); state (Extraordinary Department Secretary for World Cup-related Issues, Economic Development Department Secretary, Tourism Department Secretary and Economic Development and Environment Institute General Director). The non-probabilistic sampling adopted was the one characterized by judgement. According to Oliveira (2001) and Boddy (2016), these samples are done according to the researcher's judgement, with the word experts being a common choice about the researched topic and adopting a reasonable criteria judgement.

The study was divided into two phases. The first phase consisted of analyzing the documents connected to the 2014 World Cup in Natal, which were examined under the context of sustainability. The second phase took place in the realization of the non-structured interviews.

As for the study of these documents, we considered every kind of record and data systematization as files that could go under analyses. We adopted the analyses sense of documentation as an identification technique, data collection, browsing through the documents that were the source of the research and recording the information taken from these sources (SEVERINO, 2016). As for the realization of the interviews, besides being constituted of an information collection technique done directly with the individuals researched, they were composed of 24 questions, thus structured: $1^{\text {st }}$ part - composed of eight questions about the participants' profiles; $2^{\text {nd }}$ part - composed of three questions to identify the relationship between the participant's position and the activities connected to the World Cup; $3^{\text {rd }}$ part - composed of eleven questions aimed at verifying the participants' arguments about sustainability; $4^{\text {th }}$ part - composed of two questions aimed at identifying which effects of sustainability were left by the 2014 World Cup in Natal, RN, and recognized as such by the public state managers interviewed.

\subsection{Data processing}

With the conclusion of the proposed norms reading for the documental research and the interviews transcription, we began the collected data processing by using the content analyses technique, aiming at identifying the meaning of the messages and the enunciation extracted in relation to the sustainability dimension. The content analyses to which the data were submitted strictly followed the objective of inferring the aspects related to the presence of sustainability construction in its several dimensions.

About the topic, Bardin (2013) and Krippendorff (2018) highlights that the content analyses is a set of communication analyses techniques with a description procedure of message content, applied to the indicators obtainment (whether quantitative or not) which allow the inference of knowledge related to the conditions of production/reception (inferred variables) of these messages. From another perspective, Andrade (2013) states that this technique has two functions: the first one, which enrichens the exploratory trial and increases the discovery possibility, and the second one, which adopts hypotheses under the questioning format or temporary affirmations, which can lead to the acceptance or rejection of a confirmation. 
Notwithstanding, after the data collection was done, we began the data processing based on the orientations by Bardin (2013) and Krippendorff (2018). According to the author, these orientations are composed of three steps: on the first step, called pre-analyses, the material analyzed was organized in a way to allow an initial ideal systematization. Subdivided in four processes, they followed the following guidelines: 1 . The floating reading - opportunity that allows the researcher to define the documents, transcribe the interviews and be aware of texts to be examined; 2 . The document choice - when the researcher chooses the documents; 3. The hypotheses and objectives creation - when the researcher establishes some affirmation for verification; and 4. The indicators' elaboration - when the researcher extracts parts of the documents analyzed organizing indexes to be analyzed. Also, the criteria mentioned by the author as relevant in this selection phase of documents were checked, which are: exhaustion, representation, homogeneity and pertinence.

Still based on the scholium by Bardin (2013) and Krippendorff (2018), we followed two other steps. The second phase consisted of the material codification, the analyses elements categorization and content classification. The third phase consisted of results processing, inference and interpretation of the elements obtained, a moment in which the information for analyses was unified, with adequate highlights and reaching the interpretations and inferences that came from the researcher's intuition and reflection.

\section{RESULTS AND DISCUSSIONS}

For the realization of the 2014 World Cup, several norms were instituted with the objective of enabling this mega-sport event, which could be edited in the most variable levels of the so-called hierarchy of the norms of Kelsen (1999) - federal and state laws, decrees, ordinances, resolutions or regiments - always respecting the Federal Constitution of 1988 , which is the fundamental hypothetical norm. About this topic, the research identified, in the federal sphere, the edition of at least 6 (six) Ordinary Laws (Federal), 1 (one) Normative Decision, 8 (eight) Decrees, 3 (three) Ordinances, 4 (four) Normative Institutions and 26 (twenty-six) resolutions (Table 1).

Table 1 - Norms linked to the 2014 World Cup

\begin{tabular}{|c|c|l|}
\hline $\begin{array}{c}\text { Normative } \\
\text { type }\end{array}$ & No./Year & \multicolumn{1}{c|}{ Content } \\
\hline \multirow{5}{*}{$\begin{array}{c}\text { Ordinary } \\
\text { Laws }\end{array}$} & $12,663 / 2012$ & $\begin{array}{l}\text { Essential definitions and concepts for the realization of the 2014 } \\
\text { World Cup: Protection and exploitation of commercial rights; } \\
\text { Rules and procedures for visa concessions; the Union's civil liability } \\
\text { before FIFA; Ticket marketing for the matches; Access to the official } \\
\text { competition venues; Social campaigns during the matches; Penal } \\
\text { provisions for Law infringements. }\end{array}$ \\
\cline { 2 - 4 } & $12,462 / 2011$ & $\begin{array}{l}\text { Established the Public Procurements Differentiated Regime - } \\
\text { exclusive for contracts and bids necessary for the realization of the } \\
\text { 2014 World Cup. }\end{array}$ \\
\cline { 2 - 4 } & $12,402 / 2011$ & $\begin{array}{l}\text { Regulates the compliance of tax obligation by consortiums which } \\
\text { hire private individuals and legal entities. }\end{array}$ \\
\cline { 2 - 4 } & $12,350 / 2010$ & Tax policies related to the realization of the 2014 World Cup. \\
\cline { 2 - 4 } & $12,348 / 2010$ & City' debt limitation in loan operations. \\
\cline { 2 - 3 } & $12,309 / 2010$ & $\begin{array}{l}\text { Monthly online statement disclosure of the actions and the expenses } \\
\text { turned to the realization of the 2014 World Cup. }\end{array}$ \\
\hline
\end{tabular}




\begin{tabular}{|c|c|c|}
\hline $\begin{array}{l}\text { Normative } \\
\text { type }\end{array}$ & No./Year & Content \\
\hline $\begin{array}{l}\text { Normative } \\
\text { Decision }\end{array}$ & $510 / 2010$ & $\begin{array}{l}\text { Special Tax Regime for stadiums' construction, expansion, renovation } \\
\text { or modernization. }\end{array}$ \\
\hline \multirow{8}{*}{ Decrees } & $7,783 / 2012$ & $\begin{array}{l}\text { Foreigners' visa concession and validity; Tickets' sale and flow; } \\
\text { Adequacy and accessibility for disabled people. }\end{array}$ \\
\hline & $7,581 / 2011$ & Regulation of the Differentiated Regime Hiring. \\
\hline & $7,531 / 2011$ & Privatization of relevant airports. \\
\hline & $7,319 / 2010$ & Regulation and application of the Special Tax Regime. \\
\hline & $7,081 / 2010$ & Authorization for policemen and firefighters' training. \\
\hline & $7,034 / 2009$ & $\begin{array}{l}\text { Regulation of online disclosure of data and information pertaining } \\
\text { the } 2014 \text { World Cup. }\end{array}$ \\
\hline & $\begin{array}{l}\text { No./No., from } \\
\text { 26/07/2011 }\end{array}$ & $\begin{array}{l}\text { Changes the decree from } 14 \text { January 2010, which establishes the } \\
\text { Managing Committee should define, pass and supervise the actions } \\
\text { defined by the Brazilian Government Actions' Strategic Plan for the } \\
\text { realization of the } 2014 \text { World Cup. }\end{array}$ \\
\hline & $\begin{array}{l}\text { No./No., from } \\
14 / 01 / 2010\end{array}$ & $\begin{array}{l}\text { Creates the Managing Committee to define, pass and supervise the } \\
\text { actions defined by the Brazilian Government Actions' Strategic Plan } \\
\text { for the realization of the } 2014 \text { World Cup, among other measures. }\end{array}$ \\
\hline \multirow{3}{*}{ Ordinances } & $571 / 2010$ & $\begin{array}{l}\text { Implementation of transparency measures from the Federal } \\
\text { Government's actions. }\end{array}$ \\
\hline & $303 / 2012$ & $\begin{array}{l}\text { Appointment of the participating members of the } 2014 \text { World Cup's } \\
\text { Executive Group (GECOPA). }\end{array}$ \\
\hline & $57 / 2012$ & $\begin{array}{l}\text { Planning and execution of activities in the Brazilian scope of } \\
\text { intelligence in major events. }\end{array}$ \\
\hline \multirow{4}{*}{$\begin{array}{l}\text { Normative } \\
\text { Institutions }\end{array}$} & $62 / 2010$ & $\begin{array}{l}\text { Control of the Federal Court of Auditors over the federal resources } \\
\text { intended to the } 2014 \text { World Cup. }\end{array}$ \\
\hline & $1,293 / 2012$ & $\begin{array}{l}\text { Tax handling and temporary admission of foreign goods during the } \\
2014 \text { World Cup. }\end{array}$ \\
\hline & $1,313 / 2012$ & Rules over accessory tax obligations for legal entities. \\
\hline & $12 / 2013$ & $\begin{array}{l}\text { Importation of goods of animal and vegetal origin, from other } \\
\text { countries, for use or consumption during the } 2014 \text { World Cup events. }\end{array}$ \\
\hline \multirow{7}{*}{ Resolutions } & 1 & Authorization of the Brazil Promotion Plan. \\
\hline & $\begin{array}{l}2,6,7,8,9 \\
11,15,17,18 \\
19,22,23,24 \\
25 \text { and } 26 \\
\end{array}$ & Authorization of the Responsibility Matrix revision. \\
\hline & 3 and 4 & $\begin{array}{l}\text { Authorization of the activities of the General Union Budget; and } \\
\text { criteria necessary for approval. }\end{array}$ \\
\hline & 5,12 and 16 & $\begin{array}{l}\text { Selection of projects that are part of the Federal Government's } \\
\text { Official Program for the realization of the } 2014 \text { World Cup. }\end{array}$ \\
\hline & 10 & $\begin{array}{l}\text { Authorization of the Integrated Communication Plan for the } 2014 \\
\text { World Cup. }\end{array}$ \\
\hline & 14 & Authorization of the Tourism Plan for the 2014 World Cup. \\
\hline & 20 and 21 & $\begin{array}{l}\text { Administration of the operation of the Federal Government for the } \\
2014 \text { World Cup - Theme Areas and Work Groups. }\end{array}$ \\
\hline
\end{tabular}

Source: Elaborated by the authors

As for the second part of the study (Table 2), the interview was the tool employed in order to obtain information from the public state managers. Out of the 9 (nine) research participants, 07 (seven) public managers were questioned (with their names kept private), and they are the ones responsible for the realization of the 2014 World Cup in Natal, RN. The interviewees come 
from the high steps of the organs' management responsible for the planning and execution of the 2014 World Cup, both local and state, having previously been members of the $1^{\text {st }}$ level of functional hierarchy in their respective organs. Among the respondents, there was a time variation of position occupation, which ranged from nine months to six years, even though they were the title holders of their positions during the realization of the World Cup in Natal, RN.

As for the researchers, they all mentioned having taken part somehow in the planning or execution of the World Cup in the position of public manager of a public organ and 05 (five) of them mentioned the Natal media exposition to the world as a relevant factor to aid the touristic activities for the city.

Due to the little interviewee's time availability, some questions were done in blocks. We noticed a difficulty from the participants to answer the question about their understanding on the sustainability concept: only 1 (one) interviewee answered this question. Likewise, 06 (six) interviewees didn't answer the question about sustainability, the most important factor for society. Only 1 (one) interviewee answered this question accurately, pertaining to their area of work, that is, the six interviewees stated that the 2014 World Cup sustainability in Natal was not met. From these, 04 (four) interviewees said the absence of sustainability was because of the inexistence of previous technical projects and planning, enough to guarantee the continuation of results reached during the realization of the 2014 World Cup. They also declared that the absence of sustainability must not be attributed to FIFA or to the Federal Government, but to the public managers themselves and to the public administration as a whole.

As to the construction of the Dunas Arena and the transport complex around it, 03 (three) respondents expressed themselves positively and guaranteed these works could be seen as environmentally sustainable constructions. From these, 1 (one) answered that, besides the two constructions cited above, the Aluízio Alves International Airport building could also be seen from the environmental sustainability point of view. One other stated that a good example of sustainability is the so-called "macro drainage tunnel". However, we should highlight that, up to the realization of this interview, the macro drainage tunnel construction hadn't finished.

Among the interviewees, 03 (three) stated that one of the factors that led to the 2014 World Cup absence of sustainability in Natal, RN, was that society didn't get organized nor did it correctly represent themselves as to taking part in the works and actions execution planning and following up. Besides, from the answers we had, 04 (four) managers interviewed recognize that FIFA, holding the event's organization rights, expected that the 2014 World Cup realization in Natal, RN, would bring sustainability results for the host city, but that other factors stopped this expectation. In a complementary way, the public managers stated that few of the FIFA demands were met. From these, 1 (one) added that, in their perception, if all FIFA's demands had been met, the sustainable results for the city would have been better. Furthermore, 04 (four) managers researched assured that the 2014 World Cup realization in Natal brought positive results in several areas of development, even though they don't agree the works didn't continue. 
Table 2 - Information on state public managers who took part in the planning or execution of the 2014 World Cup in the city of Natal, Brazil

\begin{tabular}{|c|c|c|c|c|c|c|c|c|c|c|c|}
\hline Scope & Entity & MPPE & MI & MME & SM & SNM & IPP & DAC & SP & FIFA & PR \\
\hline \multirow{4}{*}{ 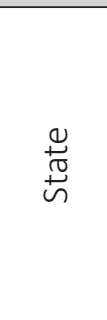 } & $\begin{array}{l}\text { Extraordinary Department for } \\
\text { World Cup-related issues. }\end{array}$ & $x$ & $x$ & $x$ & $x$ & & & & & $x$ & $x$ \\
\hline & $\begin{array}{l}\text { Department of Economic } \\
\text { Development }\end{array}$ & $x$ & $x$ & $x$ & & $x$ & $x$ & $x$ & & & $x$ \\
\hline & Department of Tourism & $x$ & $x$ & $x$ & & $x$ & $x$ & & & $X$ & $x$ \\
\hline & $\begin{array}{l}\text { Institute of Economic } \\
\text { Development and Environment }\end{array}$ & $x$ & & & & & & & & & \\
\hline \multirow{6}{*}{ ত্তু } & Department of Public Works & $x$ & $x$ & & & $x$ & $x$ & & & & \\
\hline & Department of Urban Mobility & $x$ & $x$ & & & $x$ & & $x$ & $x$ & & \\
\hline & $\begin{array}{l}\text { Department of Environment and } \\
\text { Urbanization }\end{array}$ & $x$ & $x$ & & & $x$ & & & & $x$ & \\
\hline & Department of Sport and Leisure & $x$ & & $x$ & & & & & & & \\
\hline & Department of Tourism & $x$ & $x$ & $x$ & & $x$ & $x$ & $x$ & & $x$ & $x$ \\
\hline & No. of participating managers & 9 & 7 & 5 & 1 & 6 & 4 & 3 & 1 & 4 & 4 \\
\hline \multicolumn{12}{|c|}{$\begin{array}{l}\text { Remarks: } \\
\text { MPPE: Managers who took part in the planning or execution of the } 2014 \text { World Cup. } \\
\text { MI: Managers interviewed. } \\
\text { MME: Participating managers who mentioned Natal's media exposure to the world with a relevant factor. } \\
\text { SM: Interviewee stated that the World Cup sustainability in Natal was met. } \\
\text { SNM: Interviewees stated the World Cup sustainability in Natal was not met. } \\
\text { IPP: Interviewees stated that the lack of sustainability happened due to the inexistence of technical projects } \\
\text { and planning. } \\
\text { DAC: Interviewees favorably mentioned the construction of the Dunas Arena stadium and the transport complex } \\
\text { around it, and see the constructions as environmentally sustainable. } \\
\text { SP: Interviewees stated that the lack of sustainability in the World Cup in Natal was due to the lack of social } \\
\text { participation, both in the planning and in the execution of works. } \\
\text { FIFA: Interviewees admit that FIFA brought sustainability results to Natal. } \\
\text { PR: Interviewed managers ensured that the realization of the } 2014 \text { World Cup in Natal brought positive results. }\end{array}$} \\
\hline
\end{tabular}

Source: elaborated by the authors

\section{CONCLUSION}

The World Cup realization can be understood as a relevant mega-sport event for the city and for the state that hosts it because of the economic and social impacts it brings, and because of the high investments around it.

After analyzing the definite data in the methodological processes, based on the considerations over the problematic proposed, we noticed that, according to the public state managers, the 2014 World Cup mega-event was not sustainable and it actually didn't bring any social benefits, besides the Dunas Arena construction and the transport complex around it. Besides, we noticed that the inexistence of sustainability went over the lack of popular representation when it comes to planning and following up the realization of works.

During the investigation we counted on the norms created for the World Cup realization for the existence of an intense mobilization from the Legislative and Executive Powers, nation-wide, for the creation of rules that would enable the 2014 World Cup realization in Brazil.

A good example are the forty-eight norms studied when preparing this paper, which were produced for this end and represent only a small part of the special legislation on the topic, once state and local-wise, other guidelines would certainly need to be edited due to the event 
enabling in the host cities. We should mention the diversity of interests discussed on the norms, focusing on customs rules, on taxing and product commercialization, on visa concessions, on special biddings and contracting and on national security.

Not differently, there were also measure adoptions by the Executive Power to guarantee the 2014 World Cup realization, notably when it comes to companies' contract and work and service execution directed to the event. In Natal, RN, for example, the Dunas Arena, the transport complex around it, and the Aluízio Alves International Airport, which are seen by the managers as works of difficult planning, execution and conclusion but which were relevant, not only to guarantee the World Cup realization but for the socio-economic context in the State of Rio Grande do Norte.

However, facing what had been researched, we conclude that there was no previous consideration over the requirements which could be enough for the Legislative and Executive Powers to guarantee the World Cup sustainability in Natal, RN.

As for the normative universe, in attention to the proposal of describing the devices to regulate the 2014 World Cup sustainability, we noticed that, from a total of forty-eight norms of several legislative nature, only nine of them deal with sustainability as an event realization planning. However, they are not seen as instruments that guarantee sustainability, both for their non-impositive construction and for their abstraction. Furthermore, we noticed that, besides sustainability having been little embraced by the norms identified, the only sustainability dimension met was that of environmental.

From the state managers' perception about the 2014 World Cup in Natal, we conclude that most of them realize that sustainability was not met in the realization of this mega-event, except for the Dunas Arena construction, the transport complex around it and the Aluízio Alves International Airport, this one located in the town of São Gonçalo do Amarante, in the greater Natal area.

For the local public managers, the Dunas Arena has been an example of environmental sustainability since its construction that tried to reuse all of the material from the demolition of the old state stadium João Machado - Machadão - up to its maintenance with the natural resources reuse mechanisms.

The transport complex around the Dunas Arena can be considered as a sustainable effect, under the spatial or territorial dimension (even if the association to this dimension was not mentioned by any of the interviewees), since, in the quality of urban intervention, it improved and adjusted the traffic structure and flow in the city.

We also noticed that the main reason the 2014 World Cup in Natal, RN, didn't leave any relevant effects of sustainability was the absence of technical projects and planning from the local Public Administration, which, according to the arguments taken from the public managers, strengthens the loss of opportunities of investments from the Federal Government that, at all times, made available sums for the necessary works that haven't even started, as well as the no conclusion of almost every work started. Besides, we see that, from the public managers' perception, another factor that led to the 2014 World Cup inexistence of sustainability in Natal was the lack of organization and social representation in the planning and following up of the works and actions of execution for the mega-event.

As a theoretical contribution, the investigation showed, in specific clipping about the 2014 World Cup realization, the approach of the Brazilian judicial ordering as to the sustainability topic, 
as well as presenting the public state managers' perception responsible for managing the actions for the 2014 World Cup realization in Natal, RN, under the focus of sustainable development.

The study also brought as contribution the verification of insufficient technical knowledge from the public managers about sustainability, which is seen as a suggestion for future research, as well as an exam over the participation of society in planning and following up the works and actions of execution for mega-events, especially those directly involved with Public Administration.

We also recommend analyzing how the public managers and the normative dispositions are dealing with sustainability in the planning and projects for the realization of another mega-sport events, such as the 2018 FIFA World Cup in Russia and the upcoming 2022 World Cup in Qatar.

\section{REFERENCES}

AMPONSAH, Christian Tabi; AHMED, Gouther; KUMAR, Manoj; ADAMS, Samuel. The business effects of mega-sporting events on host cities: an empirical view. Problems and perspectives in management, $v$. 16, n. 3, p. 324-36, 2018.

ACHTERBERG, Cindy; ARENDT, S. The philosophy, role, and methods of qualitative inquiry in research. In: MONSEN, E. R. (Ed.). Research: successful approaches, 3. ed., Chicago: American Dietetic Association, p. $65-74,2008$.

ANDRADE, Aurineide F. Desenvolvimento local sustentável: estudo do evento "Chuva de bala no país de Mossoró", 2013, Teacher Advisor: Fernanda Fernandes Gurgel, 112 f. Dissertation (Master in Administration), Potiguar University, Natal, Rio Grande do Norte, 2013.

ANDRADE MARTINS, Gilberto; THEÓPHILO. Carlos Renato. Metodologia da Investigação Científica Para Ciências Sociais Aplicadas. 3. ed. São Paulo: Atlas, 2016.

BACHA, Maria L.; SANTOS, Jorgina; SCHAUN, Angela. Considerações teóricas sobre o conceito de Sustentabilidade. In: SIMPÓSIO DE EXCELÊNCIA EM GESTÃO E TECNOLOGIA- SEGeT, 7., 20-22 Oct. 2010, Resende. Annals [...]. Resende, RJ, 2010.

BARDIN, Laurence. L'analyse de contenu. Paris: PUF, 2013.

BODDY, Clive Roland. Sample size for qualitative research, Qualitative Market Research: An International Journal, v. 19, n. 4 p. 426-32, 2016.

BRASIL. Ministério do Esporte. Balanços das ações do governo brasileiro para a copa de 2014. Portal da copa. 2014. Available at: http://www.copa2014.gov.br/pt-br/brasilecopa/sobreacopa/balancos. Access on: 3 July 2014.

CAPEL, Horacio. Los juegos olímpicos, entre el urbanismo, el marketing y los consensos sociales, 2010. Revista Bibliográfica de Geografía y Ciencias Sociales, Barcelona. Available at: http://www.ub.edu/geocrit/ b3w-895/b3w-895-1.htm. Access on: 11 May 2014.

CHARREIRE PETIT, Sandra; DURIEUX, Florence. Explorer et Tester. In: THIÉTART, R-A. et coll. Méthodes de recherche en management. Paris: Dunod, p. 57-80, 1999.

COTTLE, Eddie; CANTO CAPELA, Paulo Ricardo; MEIRINHO, André F. Uma lição vinda da África do Sul: os cartéis da construção estão aumentando significativamente os custos de infraestrutura da Copa do Mundo FIFA 2014 no Brasil? Motrivivência, year XXV, n. 41, p. 166-75, 2013. 
CRESWELL, John W. Research design - qualitative, quantitative, and mixed methods approaches. California: Sage, 2014.

DACOSTA, Lamartine P. Posicionando questões básicas sobre meio ambiente em megaeventos esportivos e na copa do mundo de futebol 2014 a ser realizada no Brasil. In: PENNA RODRIGUES, R.; MAGALHÃES PINTO, L. M.; TERRA, R.; DACOSTA, L. P. Legados de megaeventos esportivos. Brasília: Ministério do Esporte, 2008. p. 493-505.

DIEHL, Astor A.; TATIM, Denise C. Pesquisa em Ciências Sociais aplicadas: métodos e técnicas. São Paulo: Prentice Hall, 2004.

DOMINGUES, Edson Paulo; BETARELLI JUNIOR, Admir A.; MAGALHÃES, Aline S. Quanto vale o show? Impactos econômicos dos investimentos da Copa do Mundo 2014 no Brasil. Estudos Econômicos, São Paulo, v. 41, n. 2, p. 409-39, 2011.

ERNST \& YOUNG BRASIL. Brasil sustentável: impactos socioeconômicos da Copa do Mundo 2014. Rio de Janeiro: FGV Projetos, 2010. Available at: http://fgvprojetos.fgv.br/sites/fgvprojetos.fgv.br/files/estudo_9. pdf. Access on: 10 July 2014.

ESTENDER, Antônio Carlos; VOLPI, Almir; FITTIPALDI, Marco Aurélio. O legado da Copa do Mundo em 2014, 2011 Available at: http://www.simpoi.fgvsp.br/arquivo/2011/artigos/e2011_t00466_pcn49543. pdf. Access on: 30 July 2014.

FIGUEIREDO, Fábio F.; LIMA, Elaine C.; PONTES DE ARAÚJO, Marcelo A. Os impactos e legados nefastos dos megaeventos esportivos no Brasil: Copa do Mundo de 2014 e Jogos Olímpicos 2016. ENCONTRO DE GEÓGRAFOS DA AMÉRICA LATINA- EGAL, 14., 8 a 12 de abril de 2013, Lima, Perú. Annals [...]. Lima: CGP/ UGI, 2013. Available at: http://observatoriogeograficoamericalatina.org.mx/egal14/Geografiasocioeconomica/ Geografiacultural/31.pdf. Access on: 11 May 2014.

GASTALDO, Édison. O país do futebol mediatizado: mídia e Copa do Mundo no Brasil. Sociologias, Porto Alegre, v. 11, n. 22, p. 353-69, 2009.

GLASER, Barney G.; STRAUSS, Anselma L. La découverte de la théorie ancrée- Stratégies pour la recherche qualitative. 2. ed. Paris: Armand Colin, 2017.

GONÇALVES, Glauco Roberto. A lógica do "elefante branco": obsolescência programada do espaço na Copa de 2014. Ateliê Geográfico, Goiânia, v. 7, n. 3, p. 240-56, 2013.

JACOBI, Pedro. Educação ambiental, cidadania e sustentabilidade. Cadernos de Pesquisa, São Paulo, n. 118, p. 189-205, Mar. 2003.

KELSEN, Hans. Teoria pura do Direito. São Paulo: Martins Fontes, 1999.

KRIPPENDORFF, Klaus. Content analysis: an introduction to its methodology. 4. ed. Los Angeles: Sage, 2018.

MENDES, Jefferson Marcel C. Dimensões da Sustentabilidade. Revista das Faculdades Santa Cruz, v. 7, n. 2, 2009. Available at: http://www.santacruz.br/v4/download/revista-academica/13/cap5.pdf. Access on: 6 June 2014.

MIKHAILOVA, Irina. Sustentabilidade: evolução dos conceitos teóricos e os problemas da mensuração prática. Revista Econômica e Desenvolvimento, n. 16, 2004. Available at: https://periodicos.ufsm.br/eed/ article/view/3442/pdf. Access on: 15 May 2014.

MILES, Mattheu B.; HUBERMAN, A. Michael. Analyse des données qualitatives. Bruxelles: De Boeck, 2003. 
MINAYO, Maria Cecília S. O desafio do conhecimento: pesquisa qualitativa em saúde. São Paulo: Hucitec/ Abrasco, 2012.

MINTZBERG, Henry. An emerging strategy of 'direct' research. Administrative Science Quarterly, n. 24, p. 580-9, 1979.

MOFOKENG, Nyane E. M.; NDLOVU, Thuille P. Mega Sporting events and their structural legacies: a focused look at the attendance of Premier Soccer League games at four 2010 FIFA World Cup flagship stadia in South Africa. African Journal of Hospitality, Tourism and Leisure, n. 7, v. 2, p. 1-16, 2018.

MONZONI NETO, Mario P.; PINTO OLIVEIRA, Bárbara C.; KOSZKA KISS, Beatris C. Sustentabilidade e a Copa do Mundo de 2014: desafios e oportunidades na gestão das emissões de gases de efeito estufa. AHPCE, 2011. Available at: http://www.ahpce.org.br/newsite/attachments/category/14/Copa\%202014\%20e\%20 cO2.pdf. Access in: 2 July 2014.

OLIVEIRA, Tânia M. V. Amostragem não probabilística: adequação de situações para uso e limitações de amostras por conveniência, julgamento e quotas. Revista Administração, São Paulo, v. 2, n. 3, [s.p.], 2001.

PEREIRA, Jeferson B. Primeiras linhas sobre a Lei Geral da Copa: uma soberania ultrajada ou relativizada em face da moderna tendência globalizada, Jus Navigandi, Teresina, ano 17, n. 3124, 2012. Available at: http://jus.com.br/artigos/20899. Access on: 1 July 2014.

PREUSS, Holger. Aspectos sociais dos megaeventos esportivos. In: DA COSTA, L. P.; CORREA, D.; RIZZUTI, E.; VILLANO, B.; MIRAGAYA, A. (Ed.). Megaeventos esportivos, legado e responsabilidade social. São Paulo: Editora Casa do Psicólogo, 2007. p. 13-35.

SACHS, Ignacy. Estratégias de transição para o século XXI: desenvolvimento e meio ambiente. São Paulo: Nobel, 1993.

SEVERINO, Antônio J. Metodologia do trabalho científico. 24. ed. São Paulo: Cortez, 2016.

SILVA, Christian L.; GRASSI MENDES, Judas T. (Org.). Reflexões sobre o desenvolvimento sustentável: agentes e interações sob a ótica multidisciplinar. Petrópolis, RJ: Vozes, 2005.

SILVA, Lidiane T. C; DAMACENO, Ana Daniella; MARTINS, Maria da Conceição R.; SOBRAL, Karine M.; FARIAS, Isabel M. S. Pesquisa documental: alternativa investigativa na formação docente. In: CONGRESSO NACIONAL DE EDUCAÇÃO- EDUCERE, 9., 26-29 out. 2009. Annals [...]. Curitiba: PUCPR, 2009.

STAKE, R. Stake. Qualitative Research - studying how things work. New York: Guilford Press, 2011

STERN, Phyllis Noerager. Grounded theory methodology: its uses and processes. Image, v. 12, p. 20-23, 1980.

TAVARES, Otavio. Megaeventos Esportivos. Movimento, Porto Alegre, v. 17, n. 3, p. 11-35, 2011. Available at: http://www.pgedf.ufpr.br/downloads/Artigos\%20PS\%20Mest\%202014/Doralice/Tavares.\%20 Megaeventosesportivos.pdf. Access on: 17 May 2014.

THUMS, Jorge. Acesso à realidade: técnicas de pesquisa e construção do conhecimento. Canoas: Ulbra, 2003.

VICO, Roberto P.; UVINHA, Ricard R.; NUNO, Gustavo. Sports mega-events in the perception of the local community: the case of Itaquera region in São Paulo at the 2014 FIFA World Cup Brazil. Soccer \& Society, p. 1-14, Jan. 2018.

YIN, Robert K. Pesquisa qualitativa - do início ao fim. Porto Alegre: Penso, 2016. 


\begin{abstract}
About the authors:
César Ricardo Maia de Vasconcelos: Ph.D. in Administration from the Université Pierre Mendès France (Grenoble/France). Master's in Business Administration from the Université Pierre Mendès France (Grenoble/France) and Management and Technology of Information Systems - Option: Gestion des Systèmes d'Information from Université de Genève (Switzerland). Professor and researcher at the Potiguar University (UnP), Post-Graduate Program in Administration. E-mail: cesarmvasconcelos@gmail.com, Orcid: http://orcid.org/0000-0003-0398-5733
\end{abstract}

Fernando Cabral de Macedo Filho: Master's in Business Administration from Universidade Potiguar (UnP). Ph.D. student in Democratic Society, State and Law at Universidad del País Vasco (Spain). Graduated in Law at Universidade Potiguar. Lawyer, with expertise, especially in the areas of Civil, Administrative, Constitutional Law. E-mail: fcabralfilho@hotmail.com, Orcid: http://orcid.org/0000-0003-0885-9891 